\title{
The Challenges in Constructing and Administering an Objective Test for Beginners' Students During the COVID-19 Pandemic
}

\begin{abstract}
Shella Monica*
Doctor of Education Study Program, University of Bengkulu

*Corresponding author. Email: sellamonica945@gmail.com

ABSTRACT

A test or an exam plays important role in education since it is used as a consideration in determining the success of instruction and sorting student's grades. However, constructing and administering a good test for young learners especially during the COVID-19 pandemic is not simple. Therefore, it becomes a great challenge for every teacher especially in Indonesia. This paper aimed at presenting the challenges faced by the teachers in constructing and administering an objective test especially for elementary school students during the COVID-19 pandemic. To collect the data, semi-structured interviews were given to 5 teachers in Lubuklinggau, Bengkulu. Based on the findings, we conclude that at least there are five practical problems faced by the teachers, those dealing with the difficulty on selecting which materials should be tested; the difficulty in finding plausible distractors for multiple-choice, the difficulty to make the students clearly understand the test items, the difficulty in managing the time of the test, and the difficulty in ensuring the students to pass the test without cheating or helped by the parents.
\end{abstract}

Keywords: Challenges, Young learners. Objective test, the COVID-19 pandemic, Constructing, Test administration.

\section{INTRODUCTION}

Evaluation is a fundamental part of the teaching and learning process. Moreover, it alludes to all cycles utilized by teachers or scholarly staff to make decisions about the accomplishment of understudies in units or over a study. These cycles incorporate settling decisions about what is relevant evidence for a particular objective, how to gather and decipher the proof, and how to impart it to proposed clients (understudies, parents, university administrators, etc.) [1]. In other words, the assessment of student learning outcomes is used as an indirect process of inference involving the use of professional judgment. For this reason, when teaching students, teachers ask students to engage in behaviors or performances that they believe will lead to the desired learning outcomes, and when teachers assess that learning, habitually teachers ask students to perform tasks that they claim can only do well if the students have learned whatever is required.

Thus, it is critical when writing good assessment items to ensure that the ability to complete the tasks teachers set for students actually depends on the achievement of the desired learning outcomes that are the focus of courses and teaching. If that relationship is good, then teachers only have to concern themselves with the validity and reliability of their professional judgment. Moreover, a test or exam is a means or tool of measurement and evaluation of numerous tools such as interviews, questionnaires, problem analysis, performance evaluation, and report analysis. However, in the English classroom, tests provide teachers with basic data used to settle on choices about guidance and student grades.

Related to the statements above, based on the form and the way of scoring, at least there are two types of tests that are habitually used in the classroom settings, including subjective and objective tests. The subjective test consists of the open-ended test, complete test, essay, and interview. On another hand, a wide range of kinds of target test arrangements can be ordered into two classifications: a selected response design, in which examinees select the reaction from a given number of choices, including true/false, multiple choices, and matching test items; and a constructed response design, in which examinees are needed to deliver a whole 
reaction, including short answer test things. This differentiation is at times caught regarding acknowledgment and review [2].

However, having good skill in constructing the test items becomes an absolute requirement that must be possessed by every teacher, especially for constructing objective test items. Elegantly composed objective tests (particularly multiple-choice tests) can really evaluate such higher-request capacities somewhat. Regardless of whether the facts confirm that a few kinds of information or capacities could not be evaluated by objective tests, teachers likewise should remember that what test things can survey relies generally upon the abilities and exertion of the test constructor, rather the test design. Furthermore, in practice, the teacher is often considered trivial in constructing objective tests [3]. Unfortunately, the fact shows that developing great items of objective test requires significantly more ability, effort, and time.

Moreover, the emergency caused by the Corona virus has a wide impact in the education sector, so that in March 2020 schools were no longer be opened and it is still happening in many countries around the world. This polemic absolutely gives a negative effect on Indonesia's education sector. In the COVID-19 pandemic, teachers face enormous challenges regarding how to teach and assess their students efficiently and safely for the 2020-2021 school year. The pandemic has caused the biggest disruption of education in history, unsurprisingly all learners and teachers around the world get impacted in this pandemic, beginning from primary to secondary schools, vocational and technical education, training institutions, colleges, and until grown-up learning, and aptitudes improvement foundations. Many adaptations are needed in the teaching and learning process. E-learning becomes the only choice, the teaching and learning process runs by connecting the students into some e-learning media. Furthermore, "there are at least 12 other free applications as media and online learning resources that can be utilized during the Covid-19 pandemic; those are Rumah Belajar, Meja Kita, Icando, Indonesia X, Google for Education, Smart Class, Microsoft Office 365, Quipper School, Ruangguru, Sekolahmu, Zenius, and Cisco Webex" [4].

Unfortunately, E-learning creates new obstacles or challenges for societies. A few things that become challenges are in the use of web-based study including restricted web share or quota and the unfamiliar school personnel and also understudies in its application. Moreover, the great challenges are not only happened in the sector of teaching and learning process but it happened worse on student assessment process especially for young learners or beginners. Since the lack of literacy skills, not all test types can be given to them, mostly the teachers of beginner level students tend to use multiple-choice tests. Compared to the essay test, multiple-choice is regarded as easy in scoring and suited to students' competency that mostly still has minimum skill in reading and writing [5]. The challenges faced by the teachers when they construct and administer their students in the beginner's level are clearly presented and discussed in this study as the aim of this paper. Hopefully, it can be beneficially used by the teachers as a guideline in improving their skill in constructing students' assessment as well as creating the better education for Indonesia.

\section{THE CONCEPT OF THE TESTS}

The test has a useful and important role in education, especially in English teaching and learning process. Very oftentimes educators set up a test by investigating the substance covered during the guidance and getting ready inquiries for every territory of substance. This technique ordinarily brings about a progression of inquiries that measure how well the understudies can review what they have studied. Moreover, an assessment could be utilized to show the strength and shortcomings of the showing cycle and assist the teacher with improving it. At that point, understudies can show what ought to be given more consideration to, ought to be dealt with, and rehearsed. Besides, the aftereffects of the test will show the understudies their weak points, and if guided by the instructor, the understudies will be even ready to make any remedial moves [6].

In an English classroom, a test is used as a means that can show both the student and the teacher how much skills and knowledge have been mastered by the students from the instruction. Hence, the writer of this paper agrees and accepts that to see whether the understudies have procured the material and are gaining constant progress, the educators will unavoidably need to assign the students appropriately.

In addition, based on its form and way of scoring, the test can be divided into two; objective and subjective test. Moreover, in scoring objective tests tend to be easier than subjective tests but in opposite developing great items of objective test requires significantly more effort and ability rather than subjective test. It may be caused by objective test includes of items test that only expect understudies to choose the right answer from a few other options or to give a word or short expression to respond to an inquiry or complete an assertion.

Objective items included: multiple-choices, truefalse, matching completion. In fact, objective tests encourage some guessing and can be accurately answered through blind guessing, accordingly, numerous other explicit principles exist for building the items of objective test. Moreover, some major steps should be followed by the teachers in constructing objective tests. The initial step is the educators need to 
build up a bunch of test determinations that can serve to manage the choice of test items. Besides, a table specification or a test outline is a table that assists instructors with adjusting objectives, guidance, and also assessment [7]. Hence, this technique can be successfully utilized for an assortment of appraisal strategies yet is most generally connected with developing customary summative tests especially in the form of objective tests items.

The next step is when constructing objective tests; instructors should be worried that the test quantifies satisfactory inspecting of the class content at the psychological level that the material was educated. Besides, after specifying the substance and capacity covered by the test utilizing the table of specifications, the last step is carefully creating the appropriate specific items of the test. Therefore, test makers should be cautious and skillful enough because the test with practically no substance information could not show up at the right answer by using the qualities of the test design that are autonomous of explicit substance information. Moreover, those skills of the examinees are called "Test-Wideness" [8].

Moreover, in multiple-choice test things, all alternatives ought to be syntactically right concerning the stem (questions or incomplete statements preceding options), and catchphrases from a stem, or their equivalent words, ought not to be rehashed in the right choice. Any infringement of these principles would clearly give a favorable position to test-wise examinees. Furthermore, test writers ought to likewise balance the length of the choices of a thing and try not to utilize explicit determiners, for example, all, always, and never as some test insightful examinees realize that the right choice is oftentimes long and without such explicit determiners.

Also, there are also complete rules with itemized clarifications for developing objective test items; it is especially significant for objective test items to be written in clear and unambiguous language to permit examinees to exhibit their fulfillment of the learning goals [9][10]. If complex wording is utilized, the thing just reflects reading comprehension capacity. Nonetheless, it is additionally significant for every item of the objective test to focus on a significant part of the substance territory as opposed to trivial details. Asking trivial details not just makes the test things pointlessly troublesome, it likewise darkens what the test constructor truly needs to quantify. For the example, moderately novel material ought to be utilized while making things that measure understanding of the capacity to apply standards. Things made by duplicating sentences verbatim from a reading material just reflect repetition memory, as opposed to higher request psychological aptitudes.

\section{RESEARCH METHODS}

Through the purposive sampling technique, the five elementary teachers were involved as the participants in this study. They were selected as a recommendation of their headmaster, those teachers regarded as representative of the teacher that used an objective test in measuring their students' competences during the COVID-19 Pandemic. The teachers are then given semistructured interview that was focused on what problems they faced when constructing and administering an objective test during the COVID-19 pandemic. From the findings, the writer got the fact that the type of the test they mostly used was multiple-choice tests in form of paper-based test. That test was given to the students or their parent by calling them to come to school to bring it as "take home test" or sometimes they just send the soft copy of the test in the WhatsApp Group. Then, the result of the interview was analyzed and described descriptively by the writer.

\section{RESULTS AND DISCUSSION}

\subsection{The Challenges in Constructing and Administering an Objective Test in the COVID- 19 Era}

Having good skill in constructing an item test becomes an absolute requirement that must be possessed by every teacher. But, developing great items of objective test requires significantly more ability, effort, and time. Unfortunately, because of lack of knowledge and experience, for some teachers, constructing a good objective test is not easy work. In addition, the main problem faced by the teacher in constructing an objective test is in formulating the objective test items [11]. In line with the previous statements, based on the result of a small interview, the writer concludes that there are three practical problems that teachers habitually faced in constructing the objective test. Unsurprisingly, those problems also related to how constructing the items of the objective test itself. Then it is also related to the technical problem when the test is administered without face-to-face interaction in isolation moments during the COVID-19 pandemic. The problems in constructing objective test are presented clearly in the following below:

\subsubsection{Difficulty in Selecting which Materials Should Be Tested}

At the end of the course or units of instruction, the teachers habitually prepare a test by investigating the substance covered during the guidance and getting ready inquiries for every territory of substance. This technique ordinarily brings about a progression of inquiries that measure how well the understudies can review what they have studied from instruction or show the strength 
and weakness of the teaching process. Through the items of objective test, hopefully, teachers can decide the degree to which the expected learning results of the guidance have been accomplished by the students. Unfortunately, in constructing items of objective test, the teacher tends to feel too difficult in deciding or selecting which material should be tested by the items or included on table specification.

Moreover, based on some factors including the time of the test session and level of the student, the teachers are forced to limit the number of test items. However, it caused the teachers to feel too difficult and confused in selecting the most important material that should be tested and included on the test. For example: in the English classroom, a teacher has already taught or explained all material in one book which consists of ten chapters but the teacher cannot include all materials on the test. Thus, the teachers only can measure how much students understand the whole book only by giving them 30 items of multiple-choice. In this case, it is too difficult to decide which materials should be included in the test. Because sometimes the teachers regarded that all materials are important and must be included in the test.

\subsubsection{Difficulty in Finding Plausible Distractors for Multiple-Choice}

The alternatives in multiple-choice items contain just one right item and the distractors are obviously wrong. Another type of this item is finding the best answer in which the other options are partially right but one answer is clearly better. However, the function of the distractors should effectively occupy those understudies who do not actually know the right answer or uncertain. Therefore, the teacher should be skillful enough in finding plausible distractors for multiple-choice items.

Unfortunately, the teachers often feel it is too difficult to find appropriate distractors. Therefore, based on the result of the interview, some teachers finally solve the problems only by copying the alternatives which have been stated on the previous items. Consequently, that makes the teachers indirectly allow the students to the correct answers. Moreover, the students can easily guess the correct answer only by checking every alternative or the answers that are already presented on the previous items.

\subsubsection{Difficulty to Make the Students Clearly Understand the Test Items}

Theoretically, the teachers need to eliminate all barriers that might be faced by the students during comprehending and solving the items test by stating the items in simple or clear language. But based on the writer's own experiences as an English teacher, although the teacher had already arranged the language of the test items as simple and clear as possible, there were still some students who did not fully understand the test items. Much less, after the teacher gave the items test to the students, some students were disturbing the test sessions by always asking the meaning of some words on the direction, stem, and alternative. In consequence, during the test session, a teacher has to explain the meaning of some words that had been asked by those students carefully. Absolutely, those problems really wasted the time of the test session and disturbed other students in finishing their test.

\subsubsection{The Difficulty in Managing the Time of the Test}

Time management plays an important role in assessment. Every student must have good time management so they can answer the question effectively; therefore the number of the test items has to be equal to the duration of the test. It seems easy if the test is administered in the classroom because the teacher can easily monitor the students during the test and then collect or take the students' answer sheet if the time of the test is over. Unfortunately, since the COVID-19 pandemic, the schools are temporarily closed so the student's assessment forcefully is given to the students as a "take home test" in the form of paper-based tests or computer-based tests. In other word, more effort may be needed to manage a test through an online class while allocating the same amount of time as in a traditional class. Lack of internet connection is the most familiar reason given by the students if they cannot submit the test on time. Moreover, the other reasons are they do not clearly understand the test direction and are uncooperative or feel difficult to contact the teacher to get clarification. The last reason is they felt unfamiliar with computer-based test format or design so they tend to spend much time only typing or delivering their answer to the computer system and so on.

\subsubsection{The Difficulty in Ensuring the Students to Pass the Test Without Cheating or Helped by the Parents}

It is been almost a year since the Coronavirus crisis face the world, the concentration in many schools until college classes will essentially move from how to lead class practically to how to most viably and really evaluate understudy in an online learning [12]. It is reasonable because we can only imagine what the rate of inappropriate testing activity is when no one is watching. Absolutely, the students will be easier in cheating or just getting help from their parent in passing the test. According to the interview results, the teachers said that almost all students can pass the test perfectly (have a high score), meanwhile, those students always have bad score if the test is taking place in the classroom or the face-to-face examination. During the 
COVID-19 pandemic, student scores are highly dubious then giving rise to a big question. Is the score valid? Or have the test successfully measured what is supposed to be measured? Moreover, the most critical question is, "is it true that they did the test themselves? "Answering those questions is not easy; it will take time, effort, and deep attention. Therefore, deciding students' score and grade during the COVID-19 pandemic become a new polemic for a teacher.

\subsection{Proposed Solution}

Responding to the problems mention above, the writer thinks that an objective test regarded ineffectively used in assessing student's competence during the COVID-19 pandemic, in line with this, Denny [13] offering the solution in responding to this challenge, it is by using assign home-based performance tests and projects. For examples; for art class, the students make script scenes, rehearse music, or choreograph dances, at that point record and upload them to investigate. In addition to the fact that allows understudies to get customized feedback and unafraid of scorn from their companions, yet it shows them how to utilize a stage that they should be comfortable with for school or expert tryouts.

Additionally, another idea is proposed by Kurniawan [14], they point out that "one learning approach that can maximize online learning is project-based learning. This learning provides opportunities for students to learn concepts in depth while also being able to improve their learning outcomes." In the other words, the projectbased online learning system is learning approach that allowing the students to access teaching materials by learning about the citizens around them. They will be given important issues that occur in everyday life, especially in the learning process then they have to make a project by answering or observing those issues of real-world problems around them that will provide meaning to them. This approach can minimize the opportunity for cheating and on the other hand it can maximize students' competence as well as their observation and social skill.

\section{CONCLUSION AND SUGGESTION}

The test has a valuable and significant role in English learning. It is utilized to show both the understudy and the instructor how much the understudies have gained from the guidance. Besides, the tests additionally could be utilized to show the strength and weakness of the teaching cycle and assist the instructor in improving it. But constructing a good test is not easy, especially for objective test. Multiple choice, true-false and matching items can be accurately answered through visually impaired speculating or blind guessing.
The challenge in constructing and administering the test during the COVID-19 pandemic becomes harder since there is no face-to-face interaction between teacher and students. Absolutely, the validity of the test becomes dubious because how could we measure effectively the students' competence through the test if no one is watching them. Furthermore, not all test constructors are skillful enough in constructing a good objective test. Therefore unsurprisingly, the result of the interview shows that there are some practical problems faced by the teachers on constructing and administering an objective test. The main problem is dealing with how formulating the items of the objective test itself. The problems included, difficulty in selecting which materials should be tested, difficulty in finding plausible distracters for multiple-choice, difficulty to make the students understand clearly the test items, difficulty in managing the time of the test, and difficulty in ensuring the students pass the test without cheating or helped by the parents.

\section{REFERENCES}

[1] Heaton, J.B. Classroom testing. New York: Longman, 1990.

[2] Waugh, C. K., \& Gronlund., N. E. Assessment of students achievement (10th ed.). New York: Pearson, 2013.

[3] Ebel, R.. L., \& Frisbie, D. A. Essentials of educational measurement (5th ed.). Englewood Cliffs, NJ: Prentice Hall, 1991.

[4] Kurniawan Arizona, Zainal Abidin, Rumansyah. Pembelajaran Online Berbasis Proyek Salah Satu Solusi Kegiatan Belajar Mengajar di Tengah Pandemi Covid-19. Jurnal Ilmiah Profesi Pendidikan, $5(1)$. https://jipp.unram.ac.id/index.php/jipp/article/view /111. 2020

[5] Sari, M.H., Susetyo, Noermanzah, Wardhana, D.E.C., Kusumaningsih, D. Understanding the Level of Students' Reading Comprehension Ability. Universal Journal of Educational Research, $8(5)$. https://doi.org/10.13189/ujer.2020.080521, 2020.

[6] Heaton, J.B. Classroom testing. New York: Longman, 1990.

[7] Fives, H., \& Barnes, N. D. Classroom test construction: The power of a table of specifications. Practical assessment, research \& evaluation.18(3), 2013, 1-7. Retrieved from: http://pareonline.net/getvn.asp? $\mathrm{v}=18 \& \mathrm{n}=3$ 
[8] Millman, J., Bishop, C. H., \& Ebel, R. L. An analysis of test-wiseness. Educational and psychological measurement, 25(3), 1965, 707-726.

[9] Thorndike, R. M. Measurement and evaluation in psychology and education (6th ed.). Upper Saddle River, NJ: Merrill, 1997.

[10] Nitko, A. J. Educational assessment of students (4th ed.). Upper Saddle River, NJ: Merrill, 2004.

[11] Hanifah, N. The problems faced by social science education teachers in formulating the objective test items in instruction evaluation. Portal journal Indonesia university of education. 1(1), (48-54). 2010 .

[12] Harrison, D. Online Education And Authentic Assessment. Retrieved from: https://www.insidehighered.com/advice/2020/04/2 9/how-discourage-student-cheating-online-examsopinion, 2020.
[13] Denny, G. 6 Classroom Changes Teachers Will Make When Schools Reopen. Retrieved from https://www.edweek.org/tm/articles/2020/05/18/6classroom-changes-teachers-will-make-when.html, 2020.

[14] Kurniawan Arizona, Zainal Abidin, Rumansyah. Pembelajaran Online Berbasis Proyek Salah Satu Solusi Kegiatan Belajar Mengajar di Tengah Pandemi Covid-19. Jurnal Ilmiah Profesi Pendidikan, $5(1)$ https://jipp.unram.ac.id/index.php/jipp/article/view /111, 2020. 